\title{
Georgia Journal of College Student Affairs
}

Volume 30 | Issue 2

2014

\section{Collaborating with Academic Affairs to Cultivate Environments that Support Student Integrity}

\author{
J. Matthew Garrett
}

Alex C. Lange

Follow this and additional works at: https://digitalcommons.georgiasouthern.edu/gcpa

Part of the Higher Education Administration Commons

\section{Recommended Citation}

Garrett, J. M., \& Lange, A. C. (2014). Collaborating with Academic Affairs to Cultivate Environments that Support Student Integrity. Georgia Journal of College Student Affairs, 30(2). https://doi.org/10.20429/ gсpa.2014.300208

This research and scholarship in student affairs is brought to you for free and open access by the Journals at Digital Commons@Georgia Southern. It has been accepted for inclusion in Georgia Journal of College Student Affairs by an authorized administrator of Digital Commons@Georgia Southern. For more information, please contact digitalcommons@georgiasouthern.edu. 


\title{
Collaborating with Academic Affairs to Cultivate Environments that Support Student Integrity
}

\author{
J. Matthew Garrett, Ph.D.
}

Alex C. Lange

Integrity development has been recognized as a common outcome at many colleges and universities (Association of American Colleges \& Universities, 2012; Chickering \& Reisser, 1993; Dugan \& Komives, 2007; Higher Education Research Institute, 1996). Thus, it is important to create academic and student affairs collaborations that promote the development of students' integrity and values clarification. In this article, we briefly discuss existing and new integrity research that informs how practitioners and administrators can structure environments supportive of students' value clarification and congruence with their actions on campus. We use student Honor Codes/Codes of Conduct as an example source of collaboration on campus. 
Developing one’s personal sense of integrity has become a core outcome of today's college experience, especially as it relates to social responsibility and active citizenship in one's communities of influence (Association of American Colleges \& Universities [AAC\&U], 2012; Chickering \& Reisser, 1993; Dugan \& Komives, 2007; Higher Education Research Institute [HERI], 1996). Many of the frameworks leadership educators utilize on campus reflect some degree of integrity development (HERI, 1996; Komives, Lucas, \& McMahon, 2013; Komives, Wagner, \& Associates, 2009; Kouzes \& Posner, 1987). While integrity is recognized as an important facet of a student's development, there has been little research that has focused exclusively on integrity development. This concept is so central to higher education environments that it should be further investigated for possible collaborative activities.

In this article, we will discuss our conceptualization of integrity as well as its sub constructs. Using our frame of integrity, grounded in literature, we briefly discuss a specific study that leads practitioners to examine, more closely, the environment's influence on integrity development. The findings of the study lead us to the process-person-context-time model of Bronfenbrenner (1992) as a way to conceptualize intentional learning environments. These intentional environments are spaces for collaborative work, which in turn lead to increase learning and integrity. After reviewing the model, we discuss its implications for practice in academic and student affairs partnerships.

\section{Integrity Definition and Constructs}

The lack of a standard definition or conceptualization of integrity can create a challenge in researching the construct (Palanski \& Yammarino, 2007). There are, however, several

J. Matthew Garrett, Ph.D., Senior Director, Center for Student Leadership \& Community Engagement, Emory University

Alex C. Lange, Assistant Director of the LGBT Resource Center, Michigan State University 
characterizations of integrity in philosophical and moral reasoning literature (Stanford Encyclopedia of Philosophy, 2011). Common throughout these conceptualizations is the fact that integrity is not so much a particular set of character traits; it is rather a process and lived experience where one espouses a set of values to guide one's actions and then enacts those values in practice consistently over time, despite opposition and difficulty. Essentially, integrity is not a quality someone has, but a conviction one demonstrates repeatedly despite the difficulty of various situations (Calhoun, 1995; Chickering \& Reisser, 1993; Komives et al., 2009; Palanski \& Yammarino, 2007; Schlenker, 2008; Stanford Encyclopedia of Philosophy, 2011). As people develop over time, decisions and actions become guided by internal frameworks and personal value systems (Baxter Magolda, 2001; Chickering \& Reisser, 1993; Perry, 1981). Essential to this conceptualization of integrity are two key constructs: values and congruence.

\section{Values}

Values are "desirable goals, varying in importance, that serve as guiding principles in the life of a person or other social entity” (Schwartz, 1994, p. 21). Values predict and explain behavior on individual, communal, and societal levels (Schwartz, 2006). Values help provide a foundation for behavior and intention, guiding one's actions. Values have been used to predict certain college outcomes, such as academic success (Lounsbury, Fisher, Levy, \& Welsh, 2009). Also, a review of most institutional mission statements will reveal a commitment to creating graduates who possess a system value that prepared them for successful citizenship after graduation.

\section{Congruence}

Congruence is the ongoing process where people have consistency between their sincerely held values, personal beliefs, and their actions or behavior (Chickering \& Reisser, 
1993; HERI, 1996; Miller \& Schlenker, 2011; Schlenker, 2008; Stanford Encyclopedia of Philosophy, 2011). Students who demonstrate mature levels of integrity will demonstrate actions and behaviors that are consistent with their own values, beliefs, attitudes, and emotions (Komives et al., 2009). In student affairs we need to better understand how our role, in collaboration with our academic partners, can increase this congruence and resulting personal and social integrity.

\section{Integrity Development and Student Environments}

Recent research found a link between values, congruence, identity, environments, and integrity development. Using qualitative methods situated in a constructivist paradigm (Crotty, 1998; Preissle \& Grant, 2004), the primary author conducted a study to understand better the development of integrity in college students. Using a narrative inquiry approach to explore the experiences of college students as they developed their own conceptions of integrity (Connelly \& Clandenin, 1990; Mertens, 2005), the ten participants in the study, from two different institutional types, each took part in one interview ranging from 50 to 90 minutes. Students were asked questions about their values, how their values were clarified over time, and how their actions would or would not be in congruence with their values over time.

While the study had a variety of findings, there were two core findings related to integrity development that are important for the conceptualizations of partnerships: the influence of social identities and the influence of environments in values clarification. Nearly all the participants noted that various social identities (i.e. race, class, gender, sexual orientation) were salient influences that helped them develop a stronger sense of their personal values. For instance, one participant discussed how his identity as a gay man influenced his ability to show compassion or empathy to those with whom he works. Two female participants of color talked about how their 
experiences of marginalization clarified their own values around acceptance, love, and inclusion. While we as practitioners and administrators do not control the identities students bring with them to our institutions (Astin, 1993), we do control the environments in which our students live and learn. Those identities in interaction with the students' environments provided great insight through the study. Using this finding, we looked to environmental ecology literature to apply environmental theory to the development of integrity in college students.

\section{Influence of Environments in Values Identification}

As shown in the previously discussed study, it is important to pay attention to the interplay between student's identities and the environment, especially as it relates to values identification. The role of the environment and the interplay of the student's social identities at least in this study emerged as vitally important to the development of integrity and to the development of one's values. Students described the multiple, significant environments they were a part of over time that helped to shape and clarify their own values (e.g. high school, family, friends, hometowns, places of worship, etc.). As such, we need to pay particular attention to the environments we create and how we can work with partners across campus to increase the integrity of our students.

\section{Application}

"Among the perceived barriers to achieving the purposes of higher education is fragmentation of campuses and curricula” (Whitt, 2011, p. 483). Much of the student success literature has pointed to the idea of seamless learning environments, where educational purposes are aligned with policies and practices created to achieve those purposes (Kuh, 1996; Kuh, Kinzie, Schuh, Whitt, \& Associates, 2010; Pascarella \& Terenzini, 2005). As we discussed above, one's identities and their environment play a key role in their value identification and 
integrity development. Students come to college with their identities and characteristics. We, as practitioners and administrators, have the ability to affect the college environment to support students and help achieve desired learning outcomes (Astin, 1993; Nesheim et al., 2007). If students' integrity development is a core college outcome, then we must structure different levels of an environment to help achieve this intended outcome. Creating a seamless learning environment is not just the responsibility of student affairs practitioners; there must be collaboration with academic affairs (Kuh et al., 2010; Nesheim et al., 2007; Strange \& Banning, 2001).

A common collaboration that can be conceptualized to support integrity development is a student affairs-academic affairs partnership centered on student codes. For example, The Carolinian Creed at the University of South Carolina (http://www.sa.sc.edu/judicialcouncil/creed) was developed in collaboration with faculty, staff, and students and now has a dramatic impact on the behavior and integrity of students. More and more universities are establishing Honor Codes to hold students to a certain standard of academic honesty and integrity, sometimes situated in individual academic colleges and other times managed by student affairs. At some institutions, academic administrators and faculty manage academic dishonesty cases, not unlike student affairs practitioners who help to enforce the student code of conduct. More importantly, though, integrity of students is pivotal both in the academic integrity and ethical behavior of students. Both divisions want students to be honest and productive members of the campus community. Instead of focusing on which units own which processes, institutions would be better served if student and academic affairs administrators worked together to create developmentally supportive environments. For example, undergraduate students spend a great deal of time in their classrooms with faculty 
members. Depending on the students' resources, class standing, and abilities, they may also be participating in co-curricular activities, living in a residence hall, or working on research with faculty members. All of these are examples of a student's microsystems, the areas in which they spend the most time and have high interaction with during their daily lives. Oftentimes, colleges and universities will require faculty to list the academic honor code on course syllabi. Many faculty members tend to reference this portion of their syllabus on the first day of class without really reviewing it or discussing it in detail. If faculty members were to discuss the honor code in their classrooms in every class during the first week and enter into dialogue with students about its significance, students may better understand why academic dishonesty and plagiarism are not tolerated at the institution. Dialoguing with students about the honor code, rather than just telling them it's important, allows students to have a voice in the process and gives them buy-in to follow and respect the code. However, students must also know that a culture of honesty is expected in other places on campus, as well. For instance, resident assistants can host academic based programs to talk about past incidents of plagiarism and academic dishonesty and discuss how they have been or could be harmful to the campus community. They could involve faculty members or academic deans to talk about these issues.

If discussions about academic honesty and trustworthiness occur across microsystems, then students will have less gray area around what constitutes plagiarism and academic dishonesty and be able to make stronger meaning around an institution's attitudes towards academic veracity - which creates a seamless mesosystem for student learning. For instance, if every faculty member discussed the policy in their class with student affairs also sponsoring programs around honesty and integrity (e.g., values training with Greek students, etc.), students would understand that there is a campus climate that disapproves of academic dishonesty. 
However, if these messages only come from one unit, students may suspect that these policies only are enforced in certain environments (e.g., the classroom) and not in others (e.g., research labs or student organizations).

Exosystems are environments that do not contain an individual, but still have some effect on the individual. Exosystems produce messages for students about what is and what is not acceptable. For instance, while it is great that faculty members and student affairs practitioners are having important conversations with students about why academic honesty is important, if students do not see certain behaviors dealt with or investigated after being reported, students could see the institution's espoused values of academic honesty being one that is not enacted upon. Decisions about conduct proceedings and procedures for academic dishonesty claims are also exosystems, as they affect individuals even though that is not an environment (i.e. the committee or office that establishes those policies and procedures) the individual is present in. Also, if students report others' dishonesty and there is no follow-up (i.e. investigation and/or punishment, if the situation calls for it), students may perceive the lack of follow through as incongruence between institutional values and actions.

Finally, we can conceptualize macrosystems in terms of the norms and traditions of a given institution. How does the institution as a whole communicate a culture that helps students develop a personal sense of integrity? For example, some traditions that institutions allow to persist may actually run counter to the notion of students and integrity. Do fraternities and sororities promote integrity, or promote behavior that lacks congruence with institutional values? Do athletic traditions promote values of diversity and justice on our campuses, or continue to perpetuate harmful stereotypes? Are all students treated equally in academic dishonesty cases, or are some students treated differently creating a culture of mistrust or misalignment of values? 
When the institution or its leaders make mistakes, how do they own up to those mistakes and honor that their behavior was out of alignment of the values of the institution thereby setting a culture of integrity for students to model? Many times, during a campus or academic orientation for example, administrators may host sessions dedicated to the code of conduct and/or honor code of the institution; however, the better question to answer is how is the notion of integrity woven integrally into the fabric of the entire culture of the institution, or mesosystem of the environment? In addition to this session and continued conversations around academic dishonesty throughout the school year, other messages around campus culture and climate towards academic dishonesty can become the norm over time.

\section{Concluding Implications}

As practitioners, we cannot underestimate the important role the environment plays in the development of integrity. In the case of integrity, better understanding the individual student, the presses of the environment that may positively or negatively impact behavior, and the role of overall culture in promoting student integrity will be key to developing effective partnerships with academic affairs. Creating seamless learning environments that not only promote integrity through values alignment and congruence, but also promote holding one's self and their peers accountable should be a focus for student affairs practitioners. The challenge is that students enter our institutions from many other environments, yet they all converge at our institutions. It is our responsibility to help create an environment in which all of our students can thrive and learn to be people of integrity. 


\section{References}

Association of American Colleges \& Universities. (2012). A crucible moment: College learning and democracy's future. Washington, DC: Author.

Astin, A. W. (1993). Studying college impact. In What matters in college: Four critical years revisited, (pp. 1-31). San Francisco, CA: Jossey-Bass.

Baxter Magolda, M. B. (2001). Making their own way: Narratives for transforming higher education to promote self-development. Sterling, VA: Stylus Publishing.

Bronfenbrenner, U. (1992). Ecological systems theory. In R. Vasta (Ed.), Six theories of child development: Revised formulations and current issues (pp. 187-249). London, England: Jessica Kingsley.

Calhoun, C. (1995). Standing for something. The Journal of Philosophy, 92(5), 235-260.

Chickering, A.W., \& Reisser, L. (1993). Education and identity ( $2^{\text {nd }}$ ed.). San Francisco, CA: Jossey-Bass.

Connelly, F. M., \& Clandinin, D. J. (1990). Stories of experience and narrative inquiry. Educational Researcher, 19(4), 2-14.

Crotty, M. (1998). The foundations of social research: Meaning and perspective in the research process. Thousand Oaks, CA: Sage.

Dugan, J. P., \& Komives, S. R. (2007). Developing leadership capacity in college students: Findings from a national study. A report from the Multi-Institutional Study of Leadership. College Park, MD: National Clearinghouse for Leadership Programs.

Higher Education Research Institute. (1996). A social change model of leadership development: Guidebook (Version III). Los Angeles, CA: Author. 
Komives, S. R., Lucas, N., \& McMahon, T. R. (2013). Exploring leadership: For college students who want to make a difference ( $3^{\text {rd }}$ ed.). San Francisco, CA: Jossey-Bass.

Komives, S. R., Wagner, W., \& Associates. (2009). Leadership for a better world: Understanding the social change model of leadership development. San Francisco, CA: Jossey-Bass.

Kouzes, J., \& Posner, B. (1987). The leadership challenge: How to keep getting extraordinary things done in organizations. San Francisco: Jossey-Bass.

Kuh, G. D. (1996). Guiding principles for creating seamless learning environments for undergraduates. Journal of College Student Development, 37, 135 - 148.

Kuh, G. D., Kinzie, J., Schuh, J. H., Whitt, E. J., \& Associates. (2010). Student success in college: Creating conditions that matter. San Francisco, CA: Jossey-Bass.

Lounsbury, J. W., Fisher, L. A., Levy, J. J., \& Welsh, D. P. (2009). An investigation of character strengths in relation to the academic success of college students. Individual Differences Research, 7(1), 52-69.

Mertens, D. M. (2005). Research and evaluation in education and psychology: Integrating diversity with quantitative, qualitative, and mixed methods (2nd ed.). Thousand Oaks, CA: Sage.

Miller, M. L., Schlenker, B. R. (2011). Integrity and identity: Moral identity differences and preferred interpersonal reactions. European Journal of Personality, 25, 2-15.

Nesheim, B. E., Guentzel, M. J., Kellogg, A. H., McDonald, W. M., Wells, C. A., \& Whitt, E. J. (2007). Outcomes for students of student affairs-academic affairs partnership programs. Journal of College Student Development, 48(4), 435-454. 
Palanski, M. E. \& Yammarino, F. J. (2007). Integrity and leadership: Clearing the conceptual confusion. European Management Journal, 25(3), 171-184.

Pascarella, E. T., \& Terenzini R. T. (2005). How college affects students: A third decade of research (Vol. 2). San Francisco, CA: Jossey-Bass

Perry, W. G. (1981). Cognitive and ethical growth: The making of meaning. In A.W. Chickering \& Associates (Eds.), The modern American college: Responding to the new realities of diverse students and a changing society (pp. 76-116). New York: Jossey-Bass.

Preissle, J., \& Grant, L. (2004). Fieldwork traditions: Ethnography and participant observation. In K. de Marrais \& S. Lapan (Eds.), Foundations for research: Methods of inquiry in education and the social sciences, (pp. 161 - 180). Mahwah, NJ: Lawrence Erlbaum Associates.

Schlenker, B. R. (2008). Integrity and character: Implications of principled and expedient ethical ideologies. Journal of Social and Clinical Psychology, 27(10), 1078-1125.

Schwartz, S. H. (1994). Are there universal aspects in the structure and contents of human values? Journal of Social Issues, 50(4), 19-45.

Schwartz, S. H. (2006). Value orientations: Measurement, antecedents, and consequences across nations. In R. Jowell, C. Roberts, R. Fitzgerald, \& G. Eva (Eds.), Measuring attitudes cross-nationally: Lessons from the European social survey (pp. 161 - 193). London, England: Sage.

Stanford Encyclopedia of Philosophy. (2011). Integrity. Retrieved from http://plato.stanford.edu/entries/integrity/.

Strange, C. C., \& Banning, J. H. (2001). Educating by design: Creating campus learning environments that work. San Francisco, CA: Jossey-Bass. 
Whitt, E. J. (2011). Academic and student affairs partnerships. In J. H. Schuh, S. R. Jones, S. R. Harper, \& Associates. Student services: A handbook for the profession ( $5^{\text {th }}$ ed., pp. 482496). San Francisco, CA: Jossey-Bass. 